\title{
Optimasi Pola Tanam Menggunakan Program Linier (Waduk Batu Tegi, Das Way Sekampung, Lampung)
}

\author{
Anindita Hanalestari Setiawan dan Nadjadji Anwar \\ Jurusan Teknik Sipil, Fakultas Teknik Sipil dan Perencanaan, Institut Teknologi Sepuluh Nopember (ITS) \\ Jl. Arief Rahman Hakim, Surabaya 60111 Indonesia \\ e-mail:nadjadji@ce.its.ac.id
}

\begin{abstract}
Abstrak-Waduk Batu Tegi terletak di DAS Way Sekampung,SWS Way Seputih-Way Sekampung, Batu Tegi, Kecamatan Air Naningan, Kabupaten Tanggamus, Lampung. Waduk ini berfungsi sebagai penyedia air untuk irigasi, penyedia air baku, dan Pembangkit Listrik Tenaga Air (PLTA). Dengan keterbatasan volume air yang tersedia di waduk, dilakukan optimasi agar dapat mengoptimalkan kebutuhan air untuk irigasi yang menentukan intensitas tanam suatu lahan, air baku untuk sektor domestik dan non-domestik, dan potensi PLTA. Tujuan dari optimasi pola tanam adalah menentukan harga maksimal hasil panen yang dapat dihasilkan suatu lahan dengan jenis tanaman yang berbeda. Optimasi dalam kasus ini dilakukan dengan menggunakan program linier program bantu Quantity Methods for Windows. Perhitungan optimasi dengan pola tanam rencana dilakukan agar optimasi berupa intensitas tanam menghasilkan panen yang lebih maksimal jika dibandingkan dengan pola tanam eksisting. Dari hasil analisis yang telah dilakukan, didapatkan kesimpulan bahwa debit andalan $80 \%$ waduk yang terbesar adalah $76,7 \mathrm{~m}^{3} /$ detik yang terjadi pada Bulan Februari dan yang terkecil adah $4,30 \mathrm{~m}^{3} /$ detik yang terjadi pada Bulan Oktober, model alternatif pola tanam yang menghasilkan luas lahan dan keuntungan hasil panen paling optimum adalah Alternatif 5, besar kebutuhan air untuk irigasi dari alternatif 5 adalah 346,2 $\times 10^{6} \mathrm{~m}^{3}$ dalam satu tahun, besar kebutuhan air untuk air baku saat kondisi jam puncak pada tahun 2010 adalah $27,69 \mathrm{~m}^{3}$ $\times 10^{6} \mathrm{~m}^{3}$ dan kebutuhan air untuk PLTA adalah $734,8 \mathrm{~m}^{3} \times 10$ $\mathrm{m}^{3}$, serta keuntungan maksimal yang didapatkan dari hasil produksi lahan sawah dengan menggunakan pola tanam alternatif 5 adalah Rp 1.890.843.057.506,00.
\end{abstract}

Kata kunci - Bendungan Batu Tegi, intensitas tanam, pola tanam, studi optimasi.

\section{PENDAHULUAN}

$\mathrm{K}$ APASITAS tampungan air Waduk Batu Tegi dipengaruhi oleh inflow dari Sungai Way Sekampung dengan volume efektif waduk adalah $665 \times 10^{6} \mathrm{~m}^{3}$. Waduk Batu Tegi menyediakan $2.250 \mathrm{lt} / \mathrm{dt}$ air baku untuk air minum dan daya listrik sebesar 2 x 14 MW dari PLTA Batu Tegi. Karena dipengaruhi oleh musim kemarau dan kurangnya curah hujan, maka waduk mengalami kekurangan debit air. Diperlukan elevasi muka air setinggi $274 \mathrm{mdpl}$ untuk dapat memenuhi kebutuhan irigasi dengan lahan seluas 46.108 Ha yang mengairi 7 kabupaten/kota di Provinsi Lampung Sedangkan untuk keperluan PLTA diperlukan elevasi muka air setinggi $253 \mathrm{mdpl}$.

Kebutuhan akan hasil pertanian, energi listrik, dan air baku semakin meningkat dengan bertambahnya penduduk, oleh karena itu diperlukan peningkatan produksi pertanian, suplai energi listrik, dan sumber air baku. Salah satu upaya untuk dapat memenuhi kebutuhan tersebut, baik di musim hujan atau musim kemarau yang mempengaruhi ketersediaan air waduk, adalah dengan melakukan studi optimasi. Dampak terbesar dari ketersediaan air waduk berpengaruh pada hasil pertanian. Dari Waduk Batu Tegi, daerah irigasi yang diairi adalah Daerah Irigasi Sekampung dan Daerah Irigasi Seputih (Gambar 1). Dalam studi ini akan dilakukan optimasi Waduk

Batu Tegi untuk menghitung intensitas tanam di Daerah Irigasi Sekampung dengan total luas area 46.108 Ha untuk menghasilkan nilai hasil panen maksimal. Untuk mengoptimasi volume waduk dalam pemenuhan kebutuhan irigasi akan digunakan Linear Programming. Berikut adalah skema keseimbangan air Waduk Batu Tegi:

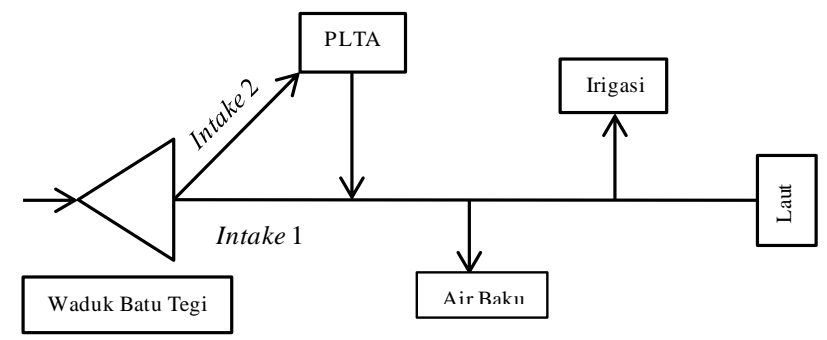

Gambar 1. Skema Keseimbangan Air Waduk

(Sumber: Katalog Badan Pelaksana Proyek Bendungan Batu Tegi, 2014)

\section{A. Perumusan Masalah}

Dengan adanya batas volume air yang dimiliki waduk, maka permasalahan yang akan dibahas adalah sebagai berikut:

1. Berapa debit andalan operasional Waduk Batu Tegi yang digunakan untuk pemanfaatan kebutuhan irigasi, air baku, dan potensi PLTA?

2. Berapa besar kebutuhan air untuk kebutuhan irigasi dari tiaptiap alternatif pola tanam?

3. Berapa besar kebutuhan air untuk air baku dan PLTA?

4. Berapa keuntungan maksimal (Rp) yang diperoleh dari hasil produksi lahan sawah setelah dilakukan optimasi pola tanam berdasarkan hasil luas tanam optimum?

\section{B. Tujuan}

Tujuan yang didapat dari penulisan penelitian ini adalah:

1. Menghitung debit andalan Waduk Batu Tegi.

2. Menghitung kebutuhan air untuk kebutuhan irigasi dari tiaptiap alternatif pola tanam.

3. Menghitung kebutuhan air untuk air baku dan PLTA.

4. Menghitung hasil produksi lahan sawah yang paling menguntungkan ( $\mathrm{Rp}$ ) setelah dilakukan optimasi pola tanam berdasarkan hasil luas tanam optimum.

\section{Manfaat}

Optimasi pola tanam ini dilakukan agar intensitas tanam baru yang dihasilkan melalui optimasi pola tanam rencana dapat menghasilkan keuntungan berupa hasil panen yang maksimal. Karena hasil panen meningkat, maka diharapkan ketersediaan bahan pangan dan kondisi ekonomi masyarakat sekitar akan meningkat. 
II. METODOLOGI

Berikut adalah diagram alir pengerjaan penelitian:

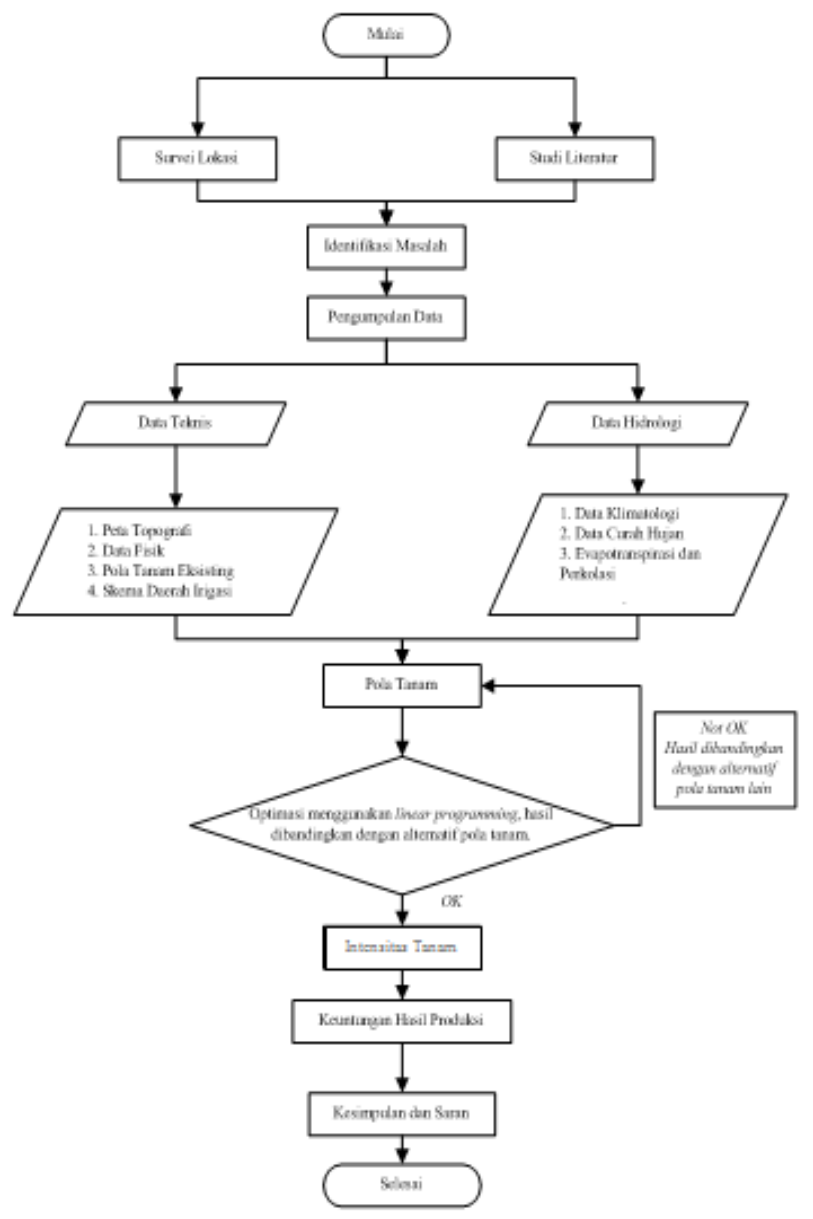

Gambar 2. Diagram Alir Pengerjaan Penelitian

\section{HASIL DAN PEMBAHASAN}

\section{A. Analisis Ketersediaan Air Waduk}

\section{A.1. Perhitungan Evapotranspirasi Potensial}

Perhitungan evapotranspirasi dengan menggunakan metode Penman modifikasi [1] memerlukan data temperatur udara, kelembapan realatif, kecepatan udara, lama penyinaran matahari, dan kecepatan angin suatu daerah. Berikut adalah perhitungan nilai evapotranspirasi potensial:

Tabel 1.

Data Klimatologi dan Perhitungan Evapotranspirasi Potensial

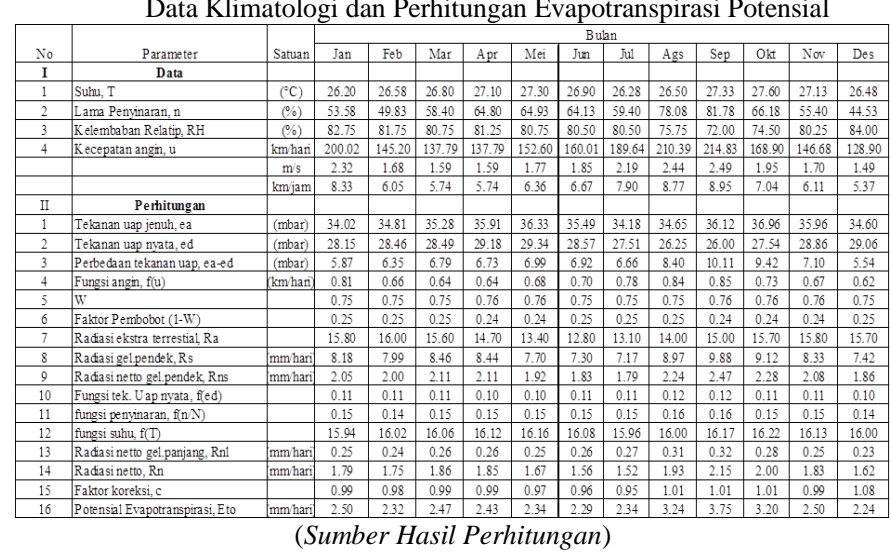

\section{A.2. Perhitungan Debit Andalan}

Perhitungan debit menggunakan debit operasional waduk yang bersumber dari data sekunder. Untuk menghitung debit andalan, ditetapkan peluang $80 \%$ dari debit inflow sumber air pada pencatatan debit dalam periode 2001-2010, seperti tabel berikut:
Tabel 2.

Rekap Perhitungan Debit Andalan ( $\mathrm{m}^{3} /$ detik)

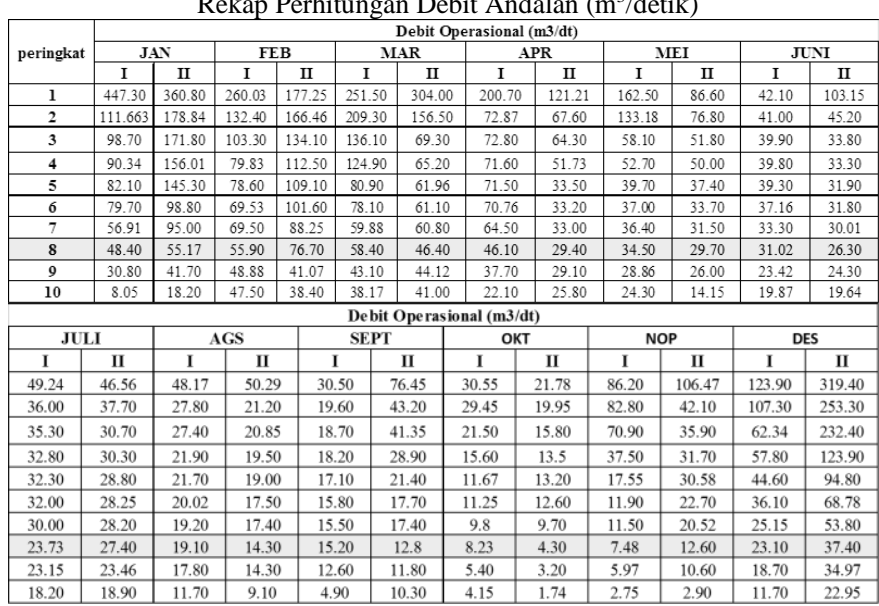

(Sumber Hasil Perhitungan)

\section{B. Analisis Kebutuhan Air untuk Irigasi}

\section{B.1 Perhtiungan Curah Hujan Efektif}

Curah hujan efektif adalah curah hujan yang jatuh ke permukaan suatu daerah dan dapat digunakan tanaman untuk pertumbuhannya dalam memenuhi kehilangan air akibat evapotranspirasi, perkolasi, dan lain - lain. Perhitungan curah hujan efektif $(\operatorname{Re} 80)$ digunakan untuk kebutuhan tanaman padi dan palawija seperti tabel berikut:

Tabel 3.

Rekap Curah Hujan Efektif (Re80) (mm/hari)

\begin{tabular}{|c|c|c|c|c|c|c|c|c|c|c|c|c|}
\hline \multirow{3}{*}{ Peringkat } & \multicolumn{12}{|c|}{$\mathrm{BUL} . \mathrm{AN}(\mathrm{nm})$} \\
\hline & \multicolumn{2}{|c|}{ JAN } & \multicolumn{2}{|c|}{$\mathrm{FBB}$} & \multicolumn{2}{|c|}{ MAR } & \multicolumn{2}{|c|}{ APR } & \multicolumn{2}{|r|}{ MII } & \multicolumn{2}{|c|}{$\pi \mathrm{N}$} \\
\hline & I & II & $\mathrm{I}$ & II & I & II & $\mathrm{I}$ & II & I & II & I & II \\
\hline 1 & 175.9 & 214.1 & 1849 & 1722 & 242.6 & 1249 & 208.1 & 1036 & 107 & 74.9 & 52.5 & 111. \\
\hline 2 & 1592 & 181.2 & 1363 & 162.1 & 165.0 & 105.7 & 121.3 & 89.2 & 83 & 71.8 & 40.6 & 62.4 \\
\hline 3 & 146.6 & 136.0 & 123.8 & 142.7 & 115.5 & 94.9 & 79.8 & 78.7 & 79. & 71.5 & 31.5 & 51.6 \\
\hline 4 & 143.1 & 128.4 & 114.0 & 1405 & 108.7 & 79.7 & 71.1 & 77.7 & 48. & 56.9 & 31.4 & 51.0 \\
\hline 5 & 139.6 & 125.4 & 105.6 & 138.9 & 105.7 & 75.5 & 69.3 & 77.5 & 43. & 49.5 & 26.9 & 47.1. \\
\hline 6 & 130.8 & 123.4 & 96.9 & 124.1 & 93.1 & 71.3 & 63.3 & 71.1 & 40. & 42.9 & 21.2 & 14.6. \\
\hline 7 & 123.6 & 963 & 81.7 & 98.3 & 76.8 & 55.1 & 59.1 & 68.6 & 37.9 & 39.5 & 15.0 & 8.3 \\
\hline 8 & 107.6 & 95.3 & 80.3 & 80.6 & 76.8 & 52.2 & 51.9 & 54.1 & 35 & 35.7 & 86 & 6.2 \\
\hline 9 & 97.6 & 821 & 73.0 & 70.4 & 22.7 & 39.6 & 34.5 & 51.6 & 27. & 32.9 & 81 & 6.1 \\
\hline 10 & 663 & 79.8 & 0.8 & 68.7 & 18.3 & 36.9 & 5.9 & 21.7 & 23 & 12.1 & 15 & 3.4 \\
\hline \multicolumn{13}{|c|}{ BLLAN (mm) } \\
\hline \multicolumn{2}{|l|}{ JUL } & \multicolumn{2}{|c|}{ AGU } & \multicolumn{2}{|c|}{ SEP } & \multicolumn{2}{|c|}{ OKT } & & \multicolumn{2}{|c|}{ NOV } & \multicolumn{2}{|c|}{ DES } \\
\hline \begin{tabular}{l|l}
$\mathbf{I}$ & \\
\end{tabular} & II & I & II & I & II & I & \begin{tabular}{l|l} 
II \\
\end{tabular} & & I & II & I & II \\
\hline 51.9 & 62.1 & 72.9 & 111.9 & 72.9 & 129.1 & 63.4 & 67.8 & & 18.9 & 149.1 & 152.8 & 178.7 \\
\hline 48.3 & 56.0 & 60.4 & 96.4 & 40.5 & 79.1 & 51.6 & 67.3 & & 97.0 & 137.3 & 151.1 & 165. \\
\hline 42.7 & 56.0 & 53.7 & 77.8 & 37.8 & 72.6 & 46.5 & 64.5 & & 67.6 & 133.7 & 149.8 & 163.1 \\
\hline 39.6 & 41.5 & 41.6 & 50.6 & 26.2 & 53.6 & 43.2 & 64.2 & & 60.3 & 87.0 & 84.8 & 162.5 \\
\hline 37.5 & 34.3 & 31.0 & 41.8 & 17.5 & 28.8 & 42.6 & 55.1 & & 44.7 & 83.7 & 64.1 & 130. \\
\hline 36.7 & 32.7 & 30.3 & 23.4 & 11.2 & 23.6 & 38.7 & 42.3 & & 44.0 & 79.1 & 57.6 & 94.1 \\
\hline 21.9 & 27.8 & 27.0 & 22.3 & 5.1 & 22.6 & 35.5 & 40.1 & & 42.8 & 77.0 & 53.4 & 91.4 \\
\hline 21.3 & 25.9 & 16.6 & 19.0 & 3.8 & 15.8 & 30.2 & 38.2 & & 40.3 & 61.4 & 51.8 & 63.1 \\
\hline 19.8 & 17.7 & 1.8 & 17.4 & 2.5 & 11.4 & 25.5 & 30.2 & & 31.8 & 32.5 & 31.1 & 54.0 \\
\hline 9.2 & 4.3 & 0.0 & 0.0 & 0.0 & 6.2 & 23.5 & 22.2 & & 27.3 & 22.0 & 12.1 & 47.3 \\
\hline
\end{tabular}

(Sumber Hasil Perhitungan)

Tabel 4.

Rekap Curah Hujan Efektif (Tanaman Palawija) (mm/hari)

\begin{tabular}{|c|c|c|c|c|c|c|c|c|}
\hline \multirow{2}{*}{ Bulan } & \multirow{2}{*}{ Periode } & \multirow{2}{*}{$\begin{array}{c}\text { Reso } \\
\mathrm{m} / 1 \text { hari }\end{array}$} & \multirow{2}{*}{$\begin{array}{l}50 \% \text { Re } 80 \\
\mathrm{~mm} / 15 \text { hari }\end{array}$} & \multirow{2}{*}{$\begin{array}{c}\mathrm{Re} \\
\mathrm{mm} / \mathrm{hln}\end{array}$} & \multirow{2}{*}{$\begin{array}{c}\text { Eto } \\
\mathrm{mm} / \mathrm{bulan}\end{array}$} & \multirow{2}{*}{$\mathrm{fD}$} & \multicolumn{2}{|r|}{ Re kede hi } \\
\hline & & & & & & & $\mathrm{mm} / \mathrm{bln}$ & $\mathrm{mm} / 1$ 5hari \\
\hline 1 & 2 & 3 & 4 & & & 7 & 8 & 9 \\
\hline \multirow{2}{*}{$\mathrm{Jan}$} & I & 107.63 & 53.81 & \multirow{2}{*}{101.46} & \multirow{2}{*}{2.50} & \multirow{2}{*}{0.76} & \multirow{2}{*}{40.85} & 20.43 \\
\hline & II & 95.30 & 47.65 & & & & & 20.43 \\
\hline \multirow{2}{*}{ Feb } & I & 80.33 & 40.16 & \multirow{2}{*}{80.45} & \multirow{2}{*}{2.32} & \multirow{2}{*}{0.76} & \multirow{2}{*}{33.34} & 16.67 \\
\hline & II & 80.58 & 40.29 & & & & & 16.67 \\
\hline \multirow{2}{*}{ Mar } & I & $\frac{76.76}{527}$ & 38.38 & \multirow{2}{*}{64.49} & \multirow{2}{*}{2.47} & \multirow{2}{*}{0.76} & \multirow{2}{*}{27.42} & 13.71 \\
\hline & II & 52.22 & 26.11 & & & & & 13.71 \\
\hline \multirow{2}{*}{ Apr } & I & 51.90 & 25.95 & \multirow{2}{*}{52.99} & \multirow{2}{*}{2.43} & \multirow{2}{*}{0.76} & \multirow{2}{*}{22.99} & 11.49 \\
\hline & II & 54.09 & 27.04 & & & & & 11.49 \\
\hline \multirow{2}{*}{ Mei } & I & 35.22 & 17.61 & \multirow{2}{*}{35.46} & \multirow[b]{2}{*}{2.34} & & & 7.94 \\
\hline & II & 35.71 & 17.85 & & & 0.76 & 15.87 & 7.94 \\
\hline $\mathrm{Jw}$ & I & 8.62 & 4.31 & 740 & 229 & 0.76 & 274 & 1.37 \\
\hline & II & 6.18 & 3.09 & & & & & 1.37 \\
\hline & I & 21.30 & 10.65 & & & & & 5.35 \\
\hline Jul & II & 25.87 & 12.94 & 23.58 & 2.34 & 0.76 & 10.70 & 5.35 \\
\hline Agust & I & 16.61 & 8.30 & 1781 & 324 & 0.76 & 804 & 4.02 \\
\hline Agाt & II & 19.00 & 9.50 & 17.01 & 0.27 & & 0.04 & 4.02 \\
\hline & I & 3.77 & 1.88 & & & & & 2.03 \\
\hline Sept & II & 15.85 & 7.92 & 9.81 & 3.75 & 0.76 & 4.05 & 2.03 \\
\hline Okt & I & 30.17 & 15.08 & 34.18 & 320 & 0.76 & 15.36 & 7.68 \\
\hline $\mathrm{okt}$ & II & 38.20 & 19.10 & 24.18 & & & & 7.68 \\
\hline Nor & I & 40.29 & 20.15 & 50.83 & 2.50 & 0.76 & 22.14 & 11.07 \\
\hline & II & 61.37 & 30.68 & & & & & 11.07 \\
\hline Des & I & 51.84 & 25.92 & 57.45 & 2.24 & 0.76 & 24.71 & 12.36 \\
\hline & II & 63.07 & 31.53 & & & & & 12.36 \\
\hline
\end{tabular}

B.2. Perhitungan Kebutuhan Air untuk Penyiapan Lahan

Kebutuhan air untuk penyiapan lahan dipengaruhi oleh perkolasi dan evapotranspirasi. Analisis kebutuhan air selama 
pengolahan lahan dapat menggunakan metode Van de Goor dan Ziljstra (1968) [2], berikut adalah rekap tabel perhitungan:

Tabel 5.

Kebutuhan Air untuk Penyiapan Lahan

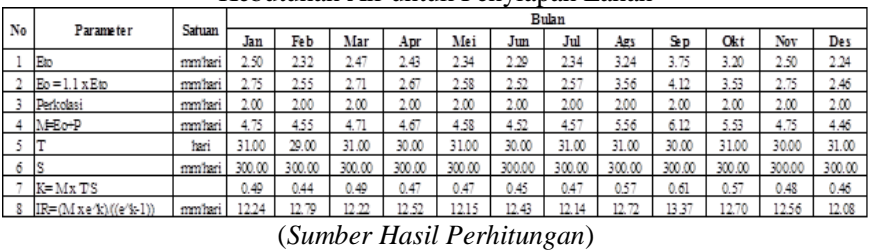

\section{B.3. Perhitungan Alternatif Pola Tanam}

Musim tanam yang digunakan dalam perencanaan pola tanam ini adalah sebagai berikut:
1. Musim tanam hujan

2. Musim tanam kemarau I

3. Musim tanam kemarau II
: Nopember - Maret.

: April - Juli.

: Agustus - Oktober. berikut:

Alternatif pola tanam yang digunakan adalah sebagai

1. Alternatif 1 : Awal tanam Bulan Nopember I.

2. Alternatif 2 : Awal tanam Bulan Nopember II.

3. Alternatif 3 : Awal tanam Bulan Desember I.

4. Alternatif 4 : Awal tanam Bulan Desember II.

5. Alternatif 5 : Awal tanam Bulan Januari I.

Berikut adalah perhitungan alternatif pola tanam 5 dengan masa awal tanam Bulan Januari I.

Tabel 6.

Perhitungan Alternatif Pola Tanam 5

\begin{tabular}{|c|c|c|c|c|c|c|c|c|c|c|c|c|c|c|c|c|c|c|c|c|c|c|c|}
\hline \multirow{3}{*}{ Bulan } & \multirow{3}{*}{ Periode } & \multirow{2}{*}{ ETo } & \multirow{2}{*}{$\mathrm{P}$} & \multirow[b]{3}{*}{$\mathrm{mm} / \mathrm{hari}$} & \multirow{3}{*}{$\frac{\text { WLR }}{\mathrm{mm} / \mathrm{hari}}$} & \multicolumn{9}{|c|}{ Padi } & \multicolumn{9}{|c|}{ Palawija Kedelai } \\
\hline & & & & & & \multirow{2}{*}{ Kc1 } & \multirow{2}{*}{$\mathrm{Kc} 2$} & \multirow{2}{*}{$\mathrm{Kc} 3$} & \multirow{2}{*}{$\mathrm{Kc}$} & \multirow{2}{*}{ ETc } & \multirow{2}{*}{$\frac{\mathrm{NFR}}{\mathrm{mm} / \mathrm{hari}}$} & \multirow{2}{*}{\begin{tabular}{|c|}
$\mathrm{NFR}$ \\
$(1 / \mathrm{d} t / \mathrm{Ha})$ \\
\end{tabular}} & \multirow{2}{*}{$\begin{array}{c}\mathrm{DR} \\
(1 / \mathrm{d} t / \mathrm{Ha} \\
\end{array}$} & \multirow{2}{*}{$\begin{array}{c}\mathrm{DR} \\
(\mathrm{Vd} / \mathrm{da} / \mathrm{Ha})\end{array}$} & \multirow{2}{*}{\begin{tabular}{|l|} 
Re pal \\
$\mathrm{mm} / \mathrm{hari}$ \\
\end{tabular}} & \multirow{2}{*}{ kc1 } & \multirow{2}{*}{ kc2 } & \multirow{2}{*}{ kc3 } & \multirow{2}{*}{$\mathrm{kc}$} & \multirow{2}{*}{ ETc } & & \begin{tabular}{|l|} 
NFR \\
\end{tabular} & DR \\
\hline & & $\mathrm{mm} / \mathrm{hari}$ & $\mathrm{mm} / \mathrm{hari}$ & & & & & & & & & & & & & & & & & & mm/hari & $(\mathrm{V} / \mathrm{dt} / \mathrm{Ha})$ & $(\mathrm{d} / \mathrm{d} t / \mathrm{Ha})$ \\
\hline (1) & (2) & (3) & (4) & (5) & (6) & (7) & $(8)$ & (9) & (10) & (11) & (12) & (13) & & (14) & (15) & (16) & (17) & (18) & (19) & (20) & (21) & \begin{tabular}{|l|}
$(22)$ \\
\end{tabular} & (23) \\
\hline NOV & $\mathrm{I}$ & 2.50 & 2.00 & 1.88 & 1.10 & 0.00 & 0.95 & 1.05 & 0.67 & 1.67 & 2.89 & 0.33 & 0.51 & 0.51 & 0.74 & 0.82 & 1.00 & 1.00 & 0.94 & 2.35 & 3.61 & 0.42 & 0.64 \\
\hline & II & 2.50 & 2.00 & 2.86 & 0.85 & 0.00 & 0.00 & 0.95 & 0.32 & 0.79 & 0.78 & 0.09 & 0.14 & 0.14 & 1.11 & 0.45 & 0.82 & 1.00 & 0.76 & 1.89 & 2.79 & 0.32 & 0.50 \\
\hline DES & I & 2.24 & 2.00 & 2.42 & & & 0.00 & 0.00 & 0.00 & 0.00 & -0.42 & -0.05 & -0.07 & 0.00 & 1.24 & 0.00 & 0.45 & 0.82 & 0.42 & 0.95 & 1.71 & 0.20 & 0.31 \\
\hline & II & 2.24 & 2.00 & 2.94 & & & & 0.00 & 0.00 & 0.00 & -0.94 & -0.11 & -0.17 & 0.00 & 1.24 & 0.00 & 0.00 & 0.45 & 0.15 & 0.34 & 1.10 & 0.13 & 0.20 \\
\hline JAN & $\mathrm{I}$ & 2.50 & 2.00 & 5.02 & & LP & LP & LP & LP & 12.24 & 9.22 & 1.07 & 1.64 & 1.64 & 2.04 & 0.50 & 0.00 & 0.00 & 0.17 & 0.42 & 0.37 & 0.04 & 0.07 \\
\hline & II & 2.50 & 2.00 & 4.45 & & 1.10 & LP & LP & LP & 12.24 & 9.80 & 1.13 & 1.74 & 1.74 & 2.04 & 0.75 & 0.50 & 0.00 & 0.42 & 1.04 & 1.00 & 0.12 & 0.18 \\
\hline FEB & I & 2.32 & 2.00 & 3.75 & & 1.10 & 1.10 & $\begin{array}{ll}\text { LP } \\
\end{array}$ & LP & 12.79 & 11.04 & 1.28 & 1.97 & 1.97 & 1.67 & 1.00 & 0.75 & 0.50 & 0.75 & 1.74 & 2.07 & 0.24 & 0.37 \\
\hline & II & 2.32 & 2.00 & 3.76 & 1.10 & 1.10 & 1.10 & 1.10 & 1.10 & 2.55 & 1.89 & 0.22 & 0.34 & 0.34 & 1.67 & 1.00 & 1.00 & 0.75 & 0.92 & 2.12 & 2.46 & 0.29 & 0.44 \\
\hline MAR & $\mathrm{II}$ & 2.47 & 2.00 & 3.58 & 1.10 & 1.10 & 1.10 & 1.10 & 1.10 & 2.71 & 2.23 & 0.26 & 0.40 & 0.40 & 1.37 & 0.82 & 1.00 & 1.00 & 0.94 & 2.32 & 2.95 & 0.34 & 0.53 \\
\hline & II & 2.47 & 2.00 & 2.44 & 2.20 & 1.10 & 1.10 & 1.10 & 1.10 & 2.71 & 4.48 & 0.52 & 0.80 & 0.80 & 1.37 & 0.45 & 0.82 & 1.00 & 0.76 & 1.87 & 2.50 & 0.29 & 0.45 \\
\hline APR & $\mathrm{I}$ & 2.43 & 2.00 & 2.42 & 1.10 & 1.05 & 1.10 & 1.10 & 1.08 & 2.63 & 3.31 & 0.38 & 0.59 & 0.59 & 1.15 & 0.00 & 0.45 & 0.82 & 0.42 & 1.03 & 1.88 & 0.22 & 0.34 \\
\hline & II & 2.43 & 2.00 & 2.52 & 1.10 & 0.95 & 1.05 & 1.10 & 1.03 & 2.51 & 3.09 & 0.36 & 0.55 & 0.55 & 1.15 & 0.00 & 0.00 & 0.45 & 0.15 & 0.36 & 1.22 & 0.14 & 0.22 \\
\hline MEI & II & 2.34 & 2.00 & 1.64 & 1.10 & $\begin{array}{l}0.00 \\
\end{array}$ & 0.95 & 1.05 & 0.67 & 1.56 & 3.02 & 0.35 & 0.54 & $\begin{array}{l}0.54 \\
\end{array}$ & 0.79 & $\begin{array}{l}0.50 \\
\end{array}$ & 0.00 & 0.00 & 0.17 & 0.39 & 1.60 & 0.19 & 0.28 \\
\hline & II & 2.34 & 2.00 & 1.67 & 0.85 & 0.00 & 0.00 & 0.95 & 0.32 & 0.74 & 1.93 & 0.22 & 0.34 & 0.34 & 0.79 & 0.75 & 0.50 & 0.00 & 0.42 & 0.98 & 2.18 & 0.25 & 0.39 \\
\hline JUN & I & 2.29 & 2.00 & 0.40 & & & 0.00 & 0.00 & 0.00 & 0.00 & 1.60 & 0.18 & 0.28 & 0.28 & 0.14 & 1.00 & 0.75 & 0.50 & 0.75 & 1.72 & 3.58 & 0.42 & 0.64 \\
\hline & II & 2.29 & 2.00 & 0.29 & & & & 0.00 & 0.00 & 0.00 & 1.71 & 0.20 & 0.30 & 0.30 & 0.14 & 1.00 & 1.00 & 0.75 & 0.92 & 2.10 & 3.96 & 0.46 & 0.71 \\
\hline JUL & $\mathrm{I}$ & 2.34 & 2.00 & 0.99 & & LP & LP & LP & LP & 12.14 & 13.15 & 1.52 & 2.34 & 2.34 & 0.54 & 0.82 & 1.00 & 1.00 & 0.94 & 2.20 & 3.66 & 0.42 & 0.65 \\
\hline & II & 2.34 & 2.00 & 1.21 & & 1.10 & LP & LP & LP & 12.14 & 12.93 & 1.50 & 2.30 & 2.30 & 0.54 & 0.45 & 0.82 & 1.00 & 0.76 & 1.77 & 3.23 & 0.37 & 0.58 \\
\hline $\mathrm{AGU}$ & $I$ & 3.24 & 2.00 & 0.78 & & 1.10 & 1.10 & LP & LP & 12.72 & 13.95 & 1.61 & 2.48 & 2.48 & 0.40 & 0.00 & 0.45 & 0.82 & 0.42 & 1.37 & 2.97 & 0.34 & 0.53 \\
\hline & II & 3.24 & 2.00 & 0.89 & 1.10 & 1.10 & 1.10 & 1.10 & 1.10 & $\begin{array}{l}3.56 \\
\end{array}$ & 5.78 & 0.67 & 1.03 & 1.03 & 0.40 & 0.00 & 0.00 & 0.45 & 0.15 & 0.49 & 2.08 & 0.24 & 0.37 \\
\hline SEP & $I$ & 3.75 & 2.00 & 0.18 & 1.10 & $\begin{array}{ll}1.10 \\
\end{array}$ & 1.10 & 1.10 & 1.10 & 4.12 & 7.05 & 0.82 & 1.26 & 1.26 & 0.20 & $\begin{array}{l}0.50 \\
\end{array}$ & 0.00 & 0.00 & 0.17 & 0.62 & 2.42 & 0.28 & 0.43 \\
\hline & II & 3.75 & 2.00 & 0.74 & 2.20 & 1.10 & 1.10 & 1.10 & 1.10 & 4.12 & 7.58 & 0.88 & 1.35 & 1.35 & 0.20 & 0.75 & 0.50 & 0.00 & 0.42 & 1.56 & 3.36 & 0.39 & 0.60 \\
\hline OKT & I & 3.20 & 2.00 & 1.41 & 1.10 & 1.05 & 1.10 & 1.10 & 1.08 & 3.47 & 5.16 & 0.60 & 0.92 & 0.92 & 0.77 & 1.00 & 0.75 & 0.50 & 0.75 & 2.40 & 3.64 & 0.42 & 0.65 \\
\hline & II & 3.20 & 2.00 & 1.78 & 1.10 & 0.95 & 1.05 & 1.10 & 1.03 & 3.31 & 4.63 & 0.54 & 0.82 & 0.82 & 0.77 & 1.00 & 1.00 & 0.75 & 0.92 & 2.94 & 4.17 & 0.48 & 0.74 \\
\hline
\end{tabular}
(Sumber: Hasil Perhitungan)

\section{Analisis Kebutuhan Air untuk Air Baku}

\section{C.1. Proyeksi Jumlah Penduduk}

Perhitungan proyeksi jumlah penduduk yang mengonsums air baku dari Waduk Batu Tegi diperlukan untuk mengetahui banyaknya kebutuhan air baku. Berikut adalah perhitungan proyeksi jumlah penduduk tahun $2010-2020$.

Tabel 7

Perhitungan Proyeksi Jumlah Penduduk Tahun 2010 - 2020

\begin{tabular}{|c|c|c|}
\hline Tahun & $\mathbf{n}$ & $\begin{array}{l}\text { Proyeksi Jumlah } \\
\text { Penduduk (Jiwa) }\end{array}$ \\
\hline $\mathbf{l}$ & $\mathbf{2}$ & $\mathbf{3}$ \\
\hline 2010 & 0 & 719603 \\
\hline 2011 & 1 & 726502 \\
\hline 2012 & 2 & 733468 \\
\hline 2013 & 3 & 740501 \\
\hline 2014 & 4 & 747601 \\
\hline 2015 & 5 & 754769 \\
\hline 2016 & 6 & 762005 \\
\hline 2017 & 7 & 769311 \\
\hline 2018 & 8 & 776688 \\
\hline 2019 & 9 & 784134 \\
\hline 2020 & 10 & 791653 \\
\hline
\end{tabular}

(Sumber: Hasil Perhitungan)

\section{C.2. Perhitungan Kebutuhan Air Baku}

Dari hasil perhitungan kebutuhan air baku untuk domestik dan non-domestik wilayah DAS Sekampung, maka didapatkan total kebutuhan air baku untuk proyeksi sepuluh tahun sebagai berikut:
Tabel 8.

Jumlah Kebutuhan Air Baku Penduduk Wilayah DAS Sekampung

\begin{tabular}{|c|c|c|c|c|c|c|c|}
\hline \multirow[t]{2}{*}{ Tahun } & $\begin{array}{l}\text { Rumah } \\
\text { Tangga }\end{array}$ & Hidran & Sekolah & Pasar & Masjid & Total & TOTAL \\
\hline & It/dt & $1 t / d t$ & It/dt & $1 \mathrm{t} / \mathrm{dt}$ & $1 t / d t$ & $1 t / d t$ & m3/det \\
\hline (1) & (2) & (3) & (4) & (5) & (6) & (7) & (8) \\
\hline 2010 & $\begin{array}{l}674.63 \\
\end{array}$ & 74.96 & 10.70 & 2.08 & 1.04 & 763.41 & 0.76 \\
\hline 2011 & $\begin{array}{l}681.10 \\
\end{array}$ & 75.68 & 10.74 & 2.08 & 1.04 & 770.64 & 0.77 \\
\hline 2012 & 687.63 & 76.40 & 10.78 & 2.08 & 1.04 & 777.94 & 0.78 \\
\hline 2013 & 694.22 & 77.14 & 10.83 & 2.08 & 1.04 & 785.31 & 0.79 \\
\hline 2014 & 700.88 & 77.88 & 10.87 & 2.08 & 1.04 & 792.75 & 0.79 \\
\hline 2015 & 707.60 & 78.62 & 10.91 & 2.08 & 1.04 & 800.25 & 0.80 \\
\hline 2016 & 714.38 & 79.38 & 10.96 & 2.08 & 1.04 & 807.84 & 0.81 \\
\hline 2017 & 721.23 & 80.14 & 11.00 & 2.08 & 1.04 & 815.49 & 0.82 \\
\hline 2018 & 728.14 & 80.90 & 11.04 & 2.08 & 1.04 & 823.22 & 0.82 \\
\hline 2019 & $\begin{array}{l}735.13 \\
\end{array}$ & 81.68 & 11.08 & 2.08 & 1.04 & 831.02 & 0.83 \\
\hline 2020 & 742.17 & 8246 & 1113 & 208 & 1.04 & 838.89 & 0.84 \\
\hline
\end{tabular}

\section{Analisis Kebutuhan Air untuk Potensi PLTA}

D.1.Lengkung Durasi

Lengkung durasi atau Duration Curve digunakan untuk menentukan debit air Q90, Q80, Q75, dan Q50. Berikut adalah lengkung durasi dari debit air waduk:

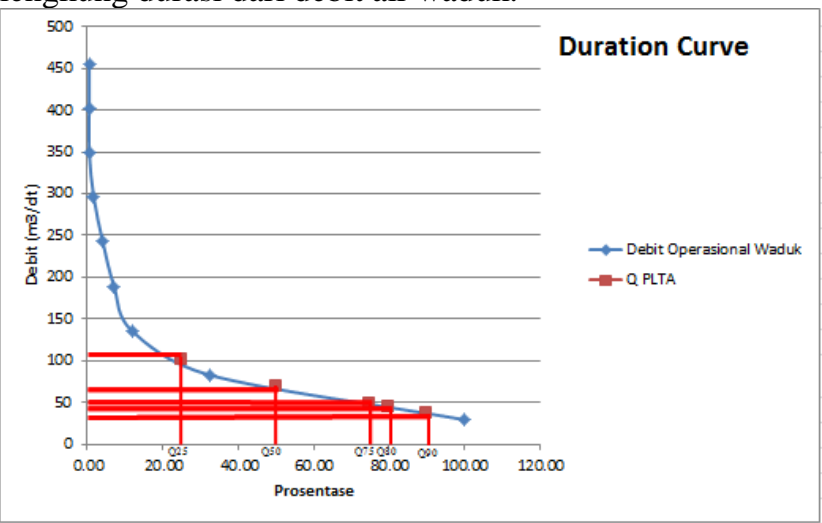

Gambar 3. Lengkung Durasi Debit PLTA

(Sumber: Hasil Perhitungan) 
Dari hasil kurva di atas, didapatkan:

Q90\% $=37,32 \mathrm{~m}^{3} /$ detik.

$\mathrm{Q} 80 \%=45,24 \mathrm{~m}^{3} /$ detik.

$\mathrm{Q} 75 \%=49,20 \mathrm{~m}^{3} /$ detik

Q50\% $=69,01 \mathrm{~m}^{3} /$ detik.

\section{D.2. Tinggi Jatuh Efektif, Heff}

Tinggi jatuh adalah selisih antara elevasi dari permukaan air di upstream dan di downstream pada Bendungan. Elevasi Upstream Bendungan Batu Tegi berada pada ketinggian +274 mdpl, sedangkan downstream berada pada ketinggian +122 mdpl.

$\mathrm{H}_{\text {eff bruto }}=$ Elevasi upstream - downstream

$\mathrm{H}_{\text {eff bruto }}=253-122=131 \mathrm{~m}$

$\mathrm{H}_{\text {eff losses }}=10 \% \times \mathrm{H}_{\text {eff bruto }}=0,10 \times 131=13,1 \mathrm{~m}$

$\mathrm{H}_{\mathrm{eff}} \quad=\mathrm{H}_{\text {eff bruto }} \times \mathrm{H}_{\text {eff losses }}=131-13,1=117,9 \mathrm{~m}$

\section{D.3. Pemilihan Jenis Turbin}

Jenis turbin ditentukan oleh tinggi jatuh efektif bendungan dan debit air di waduk. Pemilihan kategori jenis turbin yang dapat digunakan di PLTA Waduk Batu Tegi ditunjukkan pada Gambar 4.

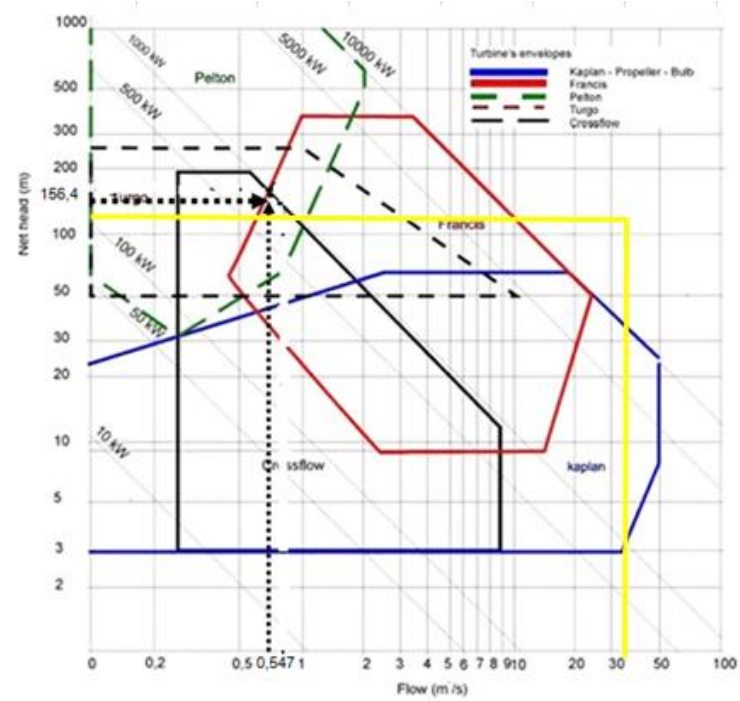

Gambar 4. Pemilihan Jenis Turbin Berdasarkan Tinggi Jatuh dan Debit PLTA (Sumber: Hasil Perhitungan)

Berdasarkan Gambar 4, turbin yang dipilih dengan tinggi jatuh efektif $117,9 \mathrm{~m}$ dan debit air sebesar $37,32 \mathrm{~m}^{3} /$ detik adalah Turbin Francis(efisiensi 85\%).

\section{D.4. Daya Listrik}

$$
\begin{array}{ll} 
& \mathrm{P}=\eta \times \rho \times \mathrm{g} \times \mathrm{H}_{\text {eff }} \times \mathrm{Q}_{90} \\
P_{90} & =0,85 \times 1 \times 9,8 \times 117,9 \times 37,32=36.652,2 \mathrm{~kW} . \\
\mathrm{P}_{80} & =0,85 \times 1 \times 9,8 \times 117,9 \times 45,24=44.430,5 \mathrm{~kW} . \\
\mathrm{P}_{75} & =0,85 \times 1 \times 9,8 \times 117,9 \times 49,20=48.319,7 \mathrm{~kW} . \\
\mathrm{P}_{50} & =0,85 \times 1 \times 9,8 \times 117,9 \times 69,01=67.775,2 \mathrm{~kW} .
\end{array}
$$

\section{D.5. Energi Listrik \\ $\mathrm{E}=\mathrm{P} \times \mathrm{t}$ \\ $=36.652,2 \mathrm{~kW} \times 365$ hari $\mathrm{x} 24 \mathrm{jam}$ \\ $=321.073 .272 \mathrm{kWh}$.}

Jadi, energi listrik yang dihasilkan oleh PLTA Batu Tegi adalah $321.073 .272 \mathrm{kWh}=321.073,3 \mathrm{mWh}$.

\section{E. Optimasi Kebutuhan Air Irigasi dengan Program Linear} Optimasi yang dilakukan berupa pemilihan keputusan dari berbagai alternatif yang telah diperhitungkan berdasarkan kebutuhan air tanaman. Digunakan program aplikasi POM-QM for Windows yang menggunakan tabel simpleks untuk membantu dalam pengoptimasian air waduk untuk irigasi. Metode simpleks mengiterasikan beberapa persamaan yang mewakili fungsi tujuan dan fungsi- fungsi kendala pada program linear yang telah disesuaikan menjadi bentuk standar [3].

Hasil dari perhitungan Alternatif Pola Tanam 1 - 5 dimasukkan ke dalam tabel simpleks untuk dilakukan iterasi dengan menggunakan program bantu POM-QM (Gambar 5). Setelah memasukkan variabel, tekan "Solve" pada taskbar dan akan muncul hasil perhitungan optimasi pola tanam (Gambar 6).

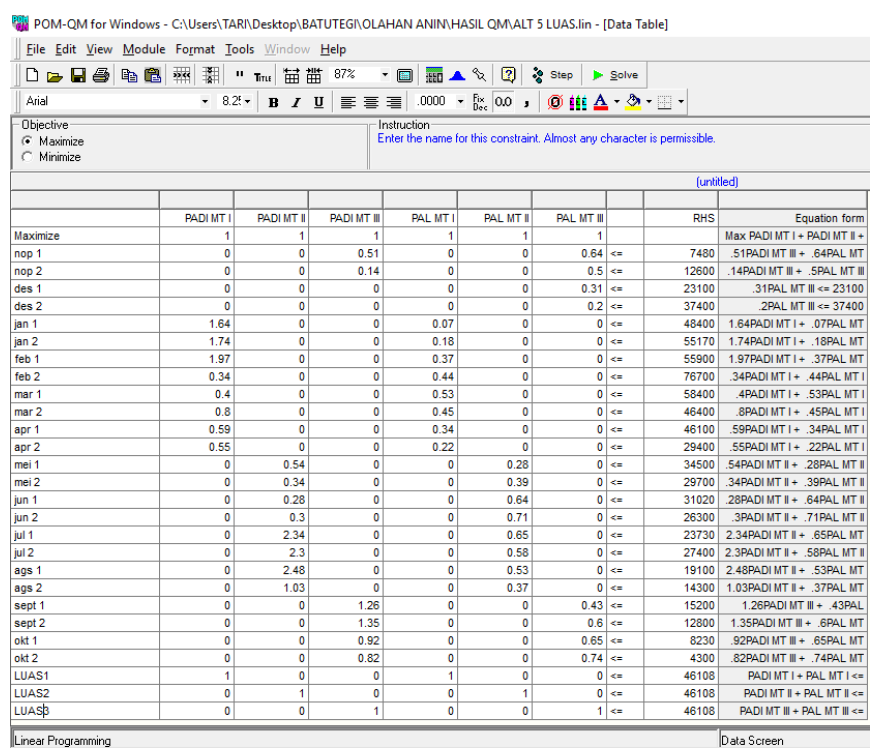

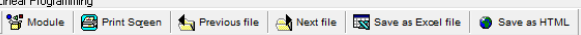

Gambar 5. Model Optimasi Alternatif Pola Tanam 5 untuk Luas Optimum Masa Tanam Januari Periode 1

(sumber: output POM QM)

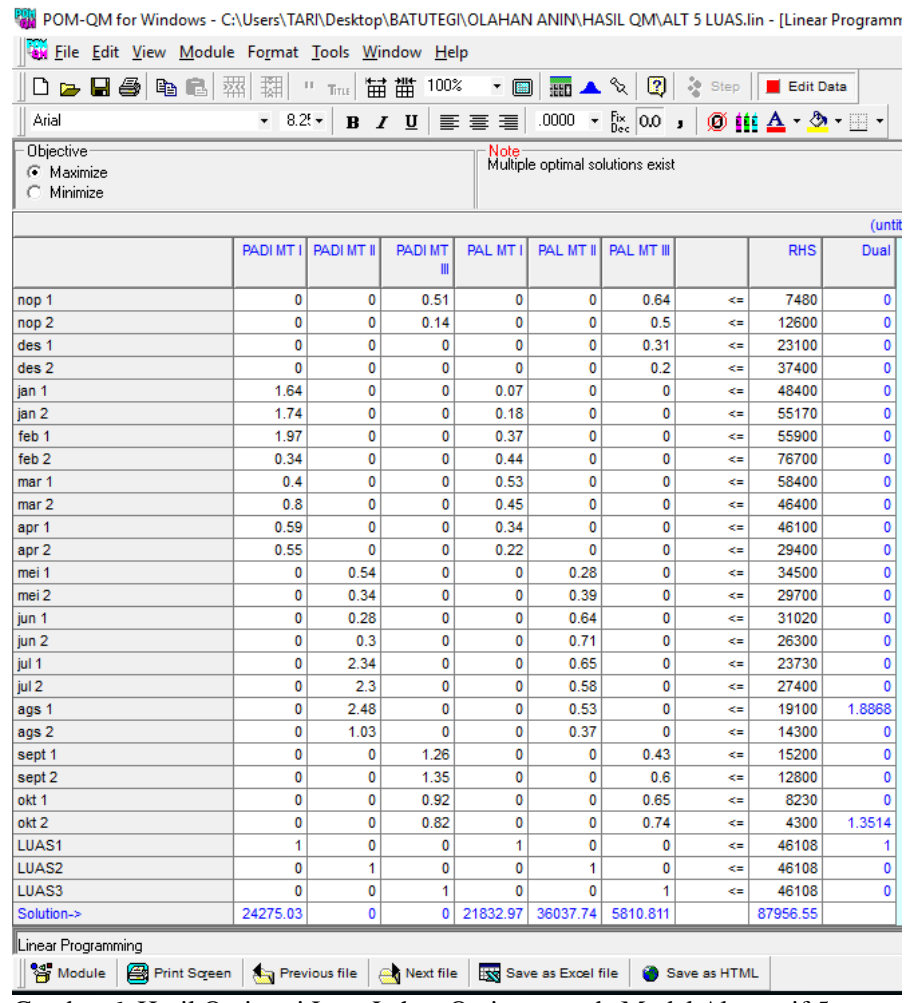

Gambar 6. Hasil Optimasi Luas Lahan Optimum pada Model Alternatif 5 (sumber: output POM QM)

Dari hasil optimasi menggunakan program bantu POM$Q M$, didapatkan luas lahan, intensitas tanam, dan harga hasil panen alternatif $1-5$ yang ditunjukkan pada Tabel 9 . 
Tabel 9.

Luas Lahan Pertanian dan Keuntungan Hasil Produksi Tiap Alternatif

\begin{tabular}{|c|c|c|c|c|c|c|c|c|c|c|c|c|c|}
\hline \multirow{2}{*}{ ALT } & \multirow{2}{*}{ Musim Tanam } & \multicolumn{2}{|c|}{ Luas Lahan ( $\mathrm{Ha})$} & \multicolumn{5}{|c|}{ Intensitas Tanam (\%) } & \multicolumn{2}{|c|}{ Produktivitas (kg.ha) } & \multicolumn{3}{|c|}{ Harga (Rp) } \\
\hline & & Padi & Palawija & Padi & Palawija & Padi & Palawija & Total & Padi & Palawija & Padi & Palawija & Total \\
\hline \multirow{3}{*}{1} & Musim Hujan & 0 & 24933.33 & 0.00 & 54.08 & \multirow{3}{*}{58.24} & \multirow{3}{*}{54.08} & \multirow{3}{*}{112.314} & \multirow{3}{*}{143660554} & \multirow{3}{*}{30593195.91} & \multirow{3}{*}{ Rp $1,221,114,709,000.00$} & \multirow{3}{*}{ Rp 226, 389, 649,734.00 } & \multirow{3}{*}{ Rp $1,447,504,358,734.0$} \\
\hline & Musim Kemarau 1 & 12408 & 0 & 26.91 & 0.00 & & & & & & & & \\
\hline & Musim Kemarau 2 & 14444.44 & 0 & 31.33 & 0.00 & & & & & & & & \\
\hline \multirow{3}{*}{2} & Musim Hujan & 1078.47 & 45029.54 & 2.34 & 97.66 & \multirow{3}{*}{52.22} & \multirow{3}{*}{97.66} & \multirow{3}{*}{149.880} & \multirow{3}{*}{128811736} & \multirow{3}{*}{55251245.58} & \multirow{3}{*}{ Rp $1,094,899,756,000.00$} & \multirow{3}{*}{ Rp 408, 859, 217,292.00 } & \multirow{3}{*}{ Rp 1,503,758,973, 29200} \\
\hline & Musim Kemarau 1 & 10436.51 & 0 & 22.63 & 0.00 & & & & & & & & \\
\hline & Musim Kemarau 2 & 12561.98 & 0 & 27.24 & 0.00 & & & & & & & & \\
\hline \multirow{3}{*}{3} & Musim Hujan & 7382.13 & 38725.87 & 16.01 & 83.99 & \multirow{3}{*}{6119} & \multirow{3}{*}{93.71} & \multirow{3}{*}{154.896} & \multirow{3}{*}{150934253.5} & \multirow{3}{*}{53015418.45} & \multirow{3}{*}{$\operatorname{Rp} 1,282,941,154,750.00$} & \multirow{3}{*}{$\operatorname{Rp} 392,314,096,530.00$} & \multirow{3}{*}{$\operatorname{Rp} 1,675,255,251,280.00$} \\
\hline & Musim Kemarau 1 & 9298.35 & 4481.48 & 20.17 & 9.72 & & & & & & & & \\
\hline & Musim Kemarau 2 & 11531.53 & 0 & 25.01 & 0.00 & & & & & & & & \\
\hline \multirow{3}{*}{4} & Musim Hujan & 15830.56 & 30277.44 & 34.33 & 65.67 & & & & & & & & \\
\hline & \begin{tabular}{|l} 
Musim Kemarau 1 \\
\end{tabular} & 10141.03 & 0 & 21.99 & 0.00 & 71.37 & 65.67 & 137.036 & 176052824.5 & 37150418.88 & Rp $1,496,449,008,250.00$ & Rp 274,913,099,712.00 & $\operatorname{Rp} 1,771,362,107,962.00$ \\
\hline & \begin{tabular}{|l} 
Musim Kemarau 2 \\
\end{tabular} & 6935.48 & 0 & 15.04 & 0.00 & & & & & & & & \\
\hline & Musim Hujan & 24275.03 & 21832.97 & 52.65 & 47.35 & & & & & & & & \\
\hline 5 & Musim Kemarau 1 & 7701.61 & 0 & 16.70 & 0.00 & 128.08 & 47.35 & 175.428 & 199129889 & 26789054.19 & Rp $1,692,604,056,500.00$ & Rp 198, 239, $001,006.00$ & Rp $1,890,843,057,506.00$ \\
\hline & Musim Kemarau 2 & 5243.9 & 0 & \begin{tabular}{|r|}
11.37 \\
\end{tabular} & 0.00 & & & & & & & & \\
\hline
\end{tabular}

(Sumber: Hasil Optimasi POM-QM dan Hasil Perhitungan)

Dari perhitungan Tabel 9, berdasarkan luas lahan dan harga panen paling optimal dan lebih menguntungkan dari keuntungan hasil panen dipilih Alternatif 5 yang menghasilkan harga hasil eksisting.

Tabel 10.

Total Kebutuhan Air Irigasi untuk Alternatif Pola Tanam 5

\begin{tabular}{|c|c|c|c|c|c|c|c|c|c|c|c|c|}
\hline \multirow{3}{*}{ Bulan } & \multirow{3}{*}{ Periode } & \multirow{3}{*}{$\begin{array}{c}\text { Jumlah } \\
\text { Hari }\end{array}$} & \multicolumn{4}{|c|}{ Padi } & \multicolumn{3}{|c|}{$\begin{array}{l}\text { Palawija } \\
\end{array}$} & \multirow[b]{2}{*}{ Total Q irigasi } & \multirow[b]{2}{*}{ Total Q irigasi } & \multirow{2}{*}{$\begin{array}{c}\text { Total } \\
\text { Kebutuhan } \\
\text { Irigasi }\end{array}$} \\
\hline & & & DR & DR & $\begin{array}{c}\text { Luas } \\
\text { daerah }\end{array}$ & $Q$ perlu & DR & $\begin{array}{c}\text { Luas } \\
\text { daerah }\end{array}$ & Q perlu & & & \\
\hline & & & It/dt/ha & lt/dt/ha & $\mathrm{Ha}$ & It/dt & It/dt/ha & Ha & lt/dt & $\mathrm{It} / \mathrm{dt}$ & $\mathrm{m} 3 / \mathrm{dt}$ & $10^{\wedge} 6 \mathrm{m3}$ \\
\hline (1) & (2) & (3) & & (4) & (5) & (6) & (7) & (8) & (9) & (10) & & (11) \\
\hline \multirow[t]{2}{*}{ NOV } & I & 15 & 0.51 & 0.51 & 24275.03 & 12481.38 & 0.64 & 21832.97 & 14080.97 & 26562.35 & 26.56 & 34.42 \\
\hline & II & 15 & 0.14 & 0.14 & 24275.03 & 3365.30 & 0.50 & 21832.97 & 10856.10 & 14221.40 & 14.22 & 18.43 \\
\hline \multirow[t]{2}{*}{ DES } & I & 15 & -0.07 & 0.00 & 24275.03 & 0.00 & 0.31 & 21832.97 & 6668.98 & 6668.98 & 6.67 & 8.64 \\
\hline & II & 16 & -0.17 & 0.00 & 24275.03 & 0.00 & 0.20 & 21832.97 & 4285.91 & 4285.91 & 4.29 & 5.92 \\
\hline \multirow[t]{2}{*}{ JAN } & $\mathrm{I}$ & 15 & 1.64 & 1.64 & 24275.03 & 39857.74 & 0.07 & 21832.97 & 1455.34 & 41313.08 & 41.31 & 53.54 \\
\hline & II & 16 & 1.74 & 1.74 & 24275.03 & 42345.04 & 0.18 & 21832.97 & 3886.98 & 46232.02 & 46.23 & 63.91 \\
\hline \multirow[t]{2}{*}{ FEB } & I & 15 & 1.97 & 1.97 & 24275.03 & 47705.54 & 0.37 & 21832.97 & 8068.63 & 55774.16 & 55.77 & 72.28 \\
\hline & II & 14 & 0.34 & 0.34 & 24275.03 & 8162.60 & 0.44 & 21832.97 & 9573.30 & 17735.90 & 17.74 & 21.45 \\
\hline \multirow[t]{2}{*}{ MAR } & $\mathrm{I}$ & 15 & 0.40 & 0.40 & 24275.03 & 9645.97 & 0.53 & 21832.97 & 11486.76 & 21132.73 & 21.13 & 27.39 \\
\hline & II & 16 & 0.80 & 0.80 & 24275.03 & 19352.02 & 0.45 & 21832.97 & 9724.45 & 29076.48 & 29.08 & 40.20 \\
\hline \multirow[t]{2}{*}{ APR } & I & 15 & 0.59 & 0.59 & 0 & 0.00 & 0.34 & 0 & 0.00 & 0.00 & 0.00 & 0.00 \\
\hline & II & 15 & 0.55 & 0.55 & 0 & 0.00 & 0.22 & 0 & 0.00 & 0.00 & 0.00 & 0.00 \\
\hline \multirow[t]{2}{*}{ MEI } & I & 15 & 0.54 & 0.54 & 0 & 0.00 & 0.28 & 0 & 0.00 & 0.00 & 0.00 & 0.00 \\
\hline & II & 16 & 0.34 & 0.34 & 0 & 0.00 & 0.39 & 0 & 0.00 & 0.00 & 0.00 & 0.00 \\
\hline \multirow[t]{2}{*}{ JUN } & I & 15 & 0.28 & 0.28 & 0 & 0.00 & 0.64 & 0 & 0.00 & 0.00 & 0.00 & 0.00 \\
\hline & II & 15 & 0.30 & 0.30 & 0 & 0.00 & 0.71 & 0 & 0.00 & 0.00 & 0.00 & 0.00 \\
\hline \multirow[t]{2}{*}{ JUL } & I & 15 & 2.34 & 2.34 & 0 & 0.00 & 0.65 & 0 & 0.00 & 0.00 & 0.00 & 0.00 \\
\hline & II & 16 & 2.30 & 2.30 & 0 & 0.00 & 0.58 & 0 & 0.00 & 0.00 & 0.00 & 0.00 \\
\hline \multirow[t]{2}{*}{ AGU } & I & 15 & 2.48 & 2.48 & 0 & 0.00 & 0.53 & 0 & 0.00 & 0.00 & 0.00 & 0.00 \\
\hline & II & 16 & 1.03 & 1.03 & 0 & 0.00 & 0.37 & 0 & 0.00 & 0.00 & 0.00 & 0.00 \\
\hline \multirow[t]{2}{*}{ SEP } & $\mathrm{I}$ & 15 & 1.26 & 1.26 & 0 & 0.00 & 0.43 & 0 & 0.00 & 0.00 & 0.00 & 0.00 \\
\hline & II & 15 & 1.35 & 1.35 & 0 & 0.00 & 0.60 & 0 & 0.00 & 0.00 & 0.00 & 0.00 \\
\hline \multirow[t]{5}{*}{ OKT } & I & 15 & 0.92 & 0.92 & 0 & 0.00 & 0.65 & 0 & 0.00 & 0.00 & 0.00 & 0.00 \\
\hline & II & 16 & 0.82 & 0.82 & 0 & 0.00 & 0.74 & 0 & 0.00 & 0.00 & 0.00 & 0.00 \\
\hline & & & & & & & & & MAX & 55774.16 & $\begin{array}{r}55.77 \\
\end{array}$ & 72.28 \\
\hline & & & & & & & & & MIN & $\begin{array}{l}0.00 \\
\end{array}$ & 0.00 & 0.00 \\
\hline & & & & & & & & & Jumlah & 263003.02 & 263.00 & 346.20 \\
\hline
\end{tabular}

(Sumber: Hasil Perhitungan)

Total kebutuhan air untuk irigasi dalam satu tahun masingmasing alternatif terdapat pada Tabel 11 berikut:

Tabel 11.

Kebutuhan Air Untuk Irigasi pada Tiap Alternatif

\begin{tabular}{|c|c|}
\hline \multirow{2}{*}{ Alternatif } & $\begin{array}{c}\text { Total Kebutuhan } \\
\text { Irigasi }\end{array}$ \\
\cline { 2 - 2 } & juta m3/tahun \\
\hline 1 & 156.15 \\
\hline 2 & 249.64 \\
\hline 3 & 524.85 \\
\hline 4 & 352.97 \\
\hline 5 & 346.20 \\
\hline
\end{tabular}

(Sumber: Hasil Perhitungan)

\section{F. Analisis Water Balance Air Waduk}

Perhitungan water balance berkaitan dengan kebutuhan air yang dikonsumsi dan ketersediaan air di waduk. Jadi, jumlah air yang masuk ke suatu sistem badan air dikurangi dengan jumlah air yang keluar atau hilang dari sistem badan air tersebut, dan tampungan waduk yang tersimpan tidak boleh habis. Berikut adalah perhitungan water balance Waduk Batu Tegi yang terdapat pada Tabel 12 . 
Tabel 12.

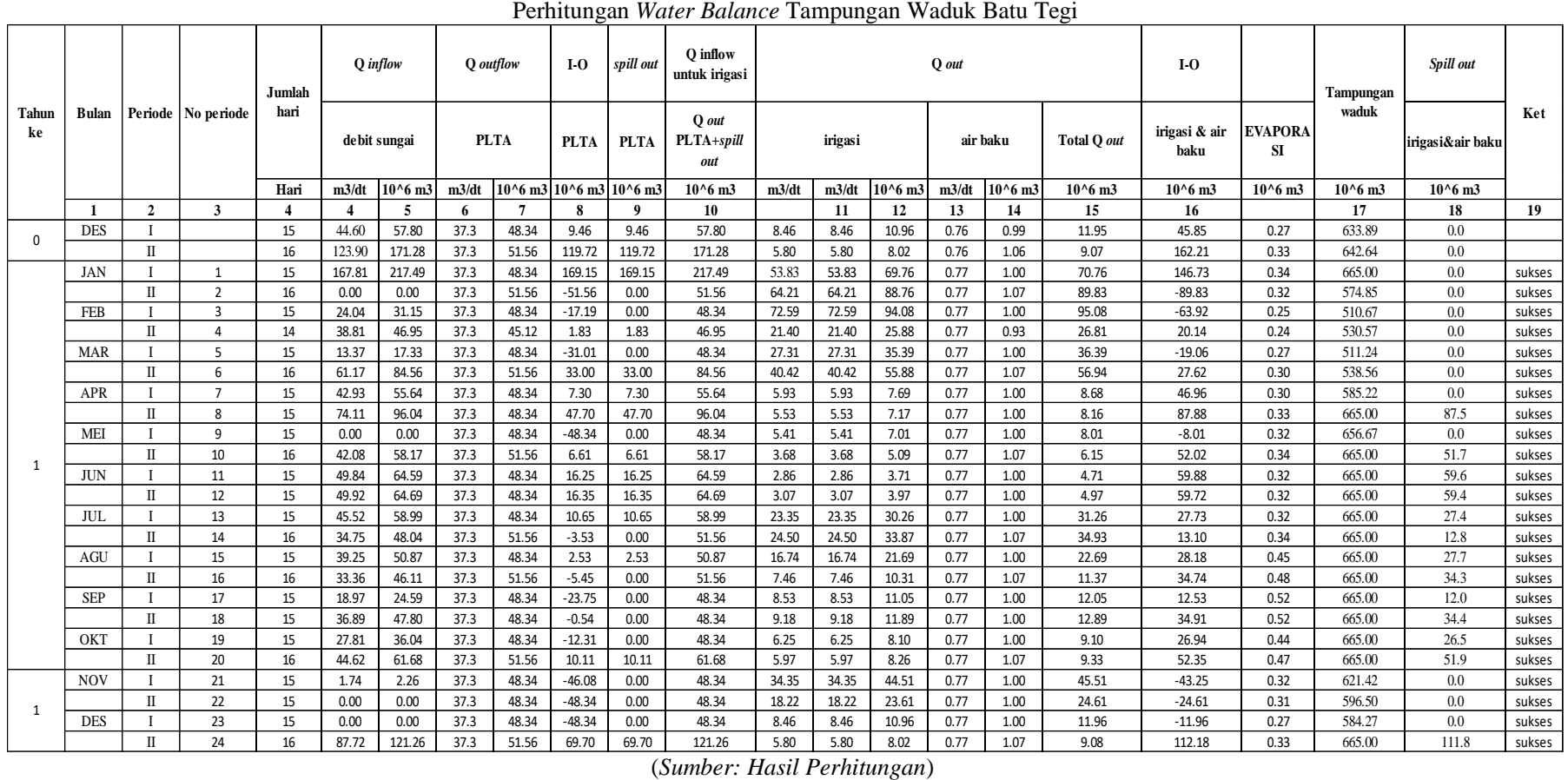

\section{G. Hasil Optimasi}

Analisis yang dilakukan terhadap optimasi pola tanam, perhitungan kebutuhan air baku, dan potensi PLTA menghasilkan nilai baru yang berpengaruh terhadap hasil keuntungan (RP), berikut adalah hasil yang didapatkan setelah melakukan perhitungan dalam studi ini:

Tabel 13.

Keuntungan Terhadap Hasil Panen, Air Baku, dan Listrik dari Waduk Batu

\begin{tabular}{|c|c|c|c|c|c|c|c|}
\hline \multicolumn{8}{|c|}{ Tegi } \\
\hline Jenis $\mathrm{P}_{1}$ & roduksi & Hasil Produktivitas & & Harga & Satuan & & Jumlah Harga \\
\hline \multirow{2}{*}{ Hasil Panen } & padi & 199129889 & IDR & $8,500.00$ & $\mathrm{~kg} / \mathrm{ha}$ & IDR & $1,692,604,056,500.00$ \\
\hline & palawija & 26789054.19 & IDR & $7,400.00$ & $\mathrm{~kg} / \mathrm{ha}$ & IDR & $198,239,001,006.00$ \\
\hline \multirow{2}{*}{\multicolumn{2}{|c|}{\begin{tabular}{|l|} 
Air Baku \\
Listrik \\
\end{tabular}}} & 24070000 & IDR & $1,250.00$ & $\mathrm{m3}$ & IDR & $30,087,500,000.00$ \\
\hline & & 321073272 & IDR & 8.36 & $\mathrm{kWh}$ & IDR & $2,683,080,904.80$ \\
\hline & & & & & TOTAL & IDR & $1,923,613,638,410.80$ \\
\hline
\end{tabular}

(Sumber: Hasil Perhitungan)

Dari tabel di atas, dapat diketahui bahwa keuntungan hasil panen dari optimasi menggunakan alternatif pola tanam 5, yaitu Rp 1.890.843.058, 00 menghasilkan nilai keuntungan sebesar $100 \%$ lebih besar jika dibandingkan dengan nilai keuntungan eksisting (Tabel 4.24). Sedangkan hasil keuntungan dari air baku dan daya listrik yang dihasilkan PLTA yang telah dihitung berdasarkan data harga dan satuan dari 'Berita Resmi Statistik, BPS Lampung 2015' menghasilkan keuntungan sebesar Rp 30.087.500,00 dan Rp 2.683.080.904,80 dalam satu tahun.

\section{KESIMPULAN DAN SARAN}

\section{A. Kesimpulan}

Dari hasil analisis dan perhitungan yang telah dilakukan, dapat diambil kesimpulan sebagai berikut:

1. Dari debit operasional waduk selama sepuluh tahun, didapatkan debit andalan $80 \%$ terbesar adalah 76,70 $\mathrm{m}^{3} /$ detik yang terjadi pada Bulan Februari, sedangkan debit andalan yang terkecil adalah $4,30 \mathrm{~m}^{3} /$ detik yang terjadi pada Bulan Oktober untuk memenuhi kebutuhan irigasi, air baku, dan potensi PLTA.

2. Besar kebutuhan air untuk kebutuhan irigasi dari tiap-tiap alternatif pola tanam dalam satu tahun adalah sebagai berikut:
a. Alternatif pola tanam $1=156,15 \times 10^{6} \mathrm{~m}^{3}$.
b. Alternatif pola tanam $2=249,64 \times 10^{6} \mathrm{~m}^{3}$.
c. Alternatif pola tanam $3=524,85 \times 10^{6} \mathrm{~m}^{3}$.
d. Alternatif pola tanam $4=352,97 \times 10^{6} \mathrm{~m}^{3}$.
e. Alternatif pola tanam $5=346,20 \times 10^{6} \mathrm{~m}^{3}$.

Alternatif pola tanam yang paling optimal adalah alternatif pola tanam 5, karena menghasilkan model optimasi dengan luas lahan dan keuntungan ( $\mathrm{Rp}$ ) paling maksimal.
3. Besar kebutuhan untuk air baku pada tahun 2010 saat kondisi normal adalah sebesar $24,07 \times 10^{6} \mathrm{~m}^{3}$, sedangkan saat kondisi jam puncak adalah $42,13 \times 10^{6} \mathrm{~m}^{3}$. Besar kebutuhan air untuk potensi PLTA tahun 2010 dengan menggunakan debit andalan $90 \%$ sebesar $37,3 \mathrm{~m}^{3} /$ detik adalah $734,8 \times 10^{6} \mathrm{~m}^{3}$ yang dapat menghasilkan energi listrik sebesar $321.073,3 \mathrm{mWh}$ dan menggunakan daya terpasang 2x19 mW.

4. Dari alternatif 5, dihasilkan intensitas tanam padi sebesar $128,08 \%$ dan intensitas tanam palawija sebesar $47,35 \%$ dalam satu tahun. Dengan intensitas tanam tersebut, dihasilkan keuntungan hasil panen sebesar Rp 1.890.843.057.506,00.

\section{B. Saran}

Berikut adalah saran yang dapat diberikan setelah melakukan analisis dan perhitungan tentang optimasi Waduk Batu Tegi:

1. Jika hasil optimasi ini akan diterapkan pada wilayah studi, maka perlu dilakukan peninjauan ulang untuk water balance dalam menghitung keseimbangan air yang masuk dan keluar dari waduk.

2. Untuk pihak lain yang berminat dalam meninjau lebih lanjut subjek ini dapat memperhitungkan debit inflow waduk dari perhitungan data curah hujan.

3. Untuk pihak lain yang akan melakukan optimasi pada wilayah studi, diperlukan adanya koreksi ulang dalam penelitian ini untuk perhitungan dengan ketelitian yang baik untuk dapat menghasilkan hasil analisis yang lebih optimal.

\section{DAFTAR PUSTAKA}

[1] Tumiar, Katarina Manik, 2012. "Evaluasi Metode Penman-Monteith dalam Menduga Laju Evapotranspirasi Standar di Dataran Rendah Propinsi Lampung, Indonesia". Jurnal Keteknikan Pertanian, 26:2.

[2] Departemen Pekerjaan Umum. 1986. Kriteria Perencanaan Bagian Jaringan Irigasi KP-01. Jakarta: Dirjen Pengairan.

[3] Anwar, Nadjadji. 2001. Analisis Sistem Untuk Teknik Sipil. Surabaya: Teknik Sipil ITS. 